\title{
FACTORS AFFECTING SUBSCRIBERS' RELATIONSHIP COMMITMENT IN THE CONTEXT OF A LEADING WIMAX INTERNET SERVICE PROVIDER IN BANGLADESH
}

\author{
MOHAMMAD MUZAHID AKBAR \\ School of Business \\ Independent University \\ Dhaka, Bangladesh
}

\begin{abstract}
This study intends to investigate the relationships of technical quality, functional quality, communication effectiveness, and trust with relationship commitment in the context of the subscribers of the leading WiMax internet service provider (WISP) in Bangladesh. It presents a critical appraisal of a few important antecedents of subscribers' relationship commitment, which eventually engenders customer loyalty. Data were collected from 172 subscribers by using a survey via the personal interview technique. Later, correlation analysis and stepwise multiple regression were carried out. All the inter-construct correlations were found to be strong and supported the hypothesized relationships with high statistical significance. In the third model identified from the stepwise multiple regression, three out of four hypotheses got supported empirically. The stepwise regression results revealed that technical quality, trust, and communication effectiveness are the significant and powerful predictors of relationship commitment respectively. Functional quality did not appear to be a statistically significant predictor of relationship commitment. A clear understanding of such important precursors of subscribers' relationship commitment might encourage the service provider(s) to indentify the needful and take necessary measures to strengthen subscribers' relationship commitment to create a loyal customer base.
\end{abstract}

Keywords: Service Quality-Technical Quality and Functional Quality, Communication Effectiveness, Trust and Relationship Commitment.

\section{Introduction}

Modem-based Broadband Internet Service (BIS) is becoming increasingly popular in Bangladesh. In Bangladesh the first internet connection was established back in 1996; the number of internet users in 2008 was only 6 lakh (Singh, 2011). Bangladesh Telecom
Regulatory Commission (BTRC) reported that currently this figure has gone up to 20 million, which reflects extraordinary growth of internet penetration in the country in recent years (Rahman, 2011). After getting the government permit, three companies started operation using WiMax (Worldwide Interoperability for Microwave Access) for 
wireless delivery of high-speed internet services covering wide geographical areas. Two leading WiMax operators, namely Banglalion (primarily focusing on expansion of service network) and Qubee (primarily focusing on innovative and user-friendly services to be the best wherever it operates) managed to start operation at the end of 2009. The newcomer Ollo started operation in October, 2011. WiMax subscribers represent less than $1 \%$ of Bangladesh's total internet users; $94 \%$ of the internet users still rely on services offered by the mobile phone operators. But people have started switching to WiMax internet services (WIS) to enjoy genuine high speed connectivity which is mobile and wireless (Rahman, 2011).

Introduction of WiMax has elevated subscribers' expectations. For serviceoriented companies, the essence of marketing is to develop long-term and value-laden relationships with the customers (Palmer \& Bejou, 1998). Theoretical underpinning of this study is relationship marketing.Emphasis - on relationship marketing has heightened ever since the firms started competing through developing relatively long-term and mutually rewarding relationships with the stakeholders (i.e. customers, suppliers, employees, and competitors) (Hunt, 2006). Hougaard and Bjerre (2002) defined relationship marketing as the behaviour of a company to establish, maintain, and develop profitable customer relationships that will be mutually rewarding for both parties.

In relationship marketing relationship commitment is considered essential for successful long-standing relationships with the customers (Anderson \& Weitz, 1992; Kumar, Scheer, \& Steenkamp, 1995). Two fundamental components of service quality, namely technical quality and functional quality are considered to be the prerequisites of lasting customer relationship with the service provider (Grönroos, 1983). Sharma and Patterson (1999) reported that effectiveness of communication between customers and service providers can play a vital role to engender customers' relationship commitment. Mukherjee and Nath (2003) identified trust as a major precursor of customer relationship commitment. Unless WiMax internet service providers (WISPs) understand and meet subscribers' expectations, they cannot expect the subscribers' to commit to the relationships they have with the service providers. Hence, this study focuses on the antecedents of relationship commitment to evaluate their predictive powers in explaining and improving the WIS subscribers' relationship commitment.

\section{Literature Review}

\section{Service Quality}

Service quality is conceptualized as the consumer's overall impression of the relative inferiority or superiority of the services (Zeithaml, Parasuraman, \& Berry, 1990). Service quality is often referred to the comparative evaluation between customer's expectation(s) regarding a service to be received and perception of the service being received (Dotchin \& Oakland, 1994; Parasuraman, Zeithaml, \& Berry, 1988). According to Imrie, Cadogan, and McNaughton (2002), service quality happens to be an important antecedent of a customer's appraisal of value.

The conceptualization or measurement of service quality happens to be the most debated topic in the domain of services marketing (Brady \& Cronin, 2001; Zeithaml, 2000; Zins, 2001). Because services are 
intangible, customers tend to assess quality subjectively. In order to measure the quality of services Parasuraman et al. (1985, 1988) developed a scale called SERVQUAL, which identified five dimensions of service quality (viz. reliability, responsiveness, assurance, empathy, and tangibles) that link specific service characteristics to customer expectations.SERVQUAL was criticized due to the difficulties related to operationalization and measurement by some researchers (Carman, 1990; Taylor, 1995). Considering the empirical issues, Carman (1990) argued that the five dimensions identified in the SERVQUAL are not generic; rather they are industry-specific.

Grönroos (1984) came up with two components-technical quality ("what" is delivered) and functional quality ("how" it is delivered) — to assess service quality and these dimensions are typically moderated by the company image. Technical quality refers to what the service process leads to for the customer in a "technical" sense. Functional quality refers to 'how' a service is provided (which may include issues like courtesy, attention, promptness, professionalism, and so on). Obviously, the functional quality dimension (which is subjective in nature) cannot be evaluated as objectively as the technical dimension.

Researchers (Oliver, 1989; Bolton \& Drew, 1991) pointed out that customers' assessments of continuously provided services (such as telephone services) may depend solely on performance. Cronin and Taylor (1992) introduced a performancebased scale for service quality called SERVPERF and discussed its superiority in terms of construct validity and operational efficacy. SERVPERF relies on assessing a service provider's performance to determine whether the service was delivered adequately and competently. Brady and Cronin (2001) advanced the hierarchical conceptualization of service quality and identified three dimensions: outcome quality (customer's appraisal of the core services), interaction quality (customer's appraisal of the servicedelivery process), and physical environment quality (consumer's appraisal of tangible aspects related to the service).

Addressing the diverse attempts of service quality assessment, no matter how novel or unique the measurement approach is, the customers tend to form a distinct overall evaluation of service quality, which eventually influences their behavioural intentions (Dabholkar, Shepherd, \& Thorpe, 2000). It is evident that the conceptualization of service quality is not a simple task, which operates at various levels of abstraction (Carman, 1990; Brady \& Cronin, 2001). Dimensions of service quality differ mainly in their level of aggregation (Brady \& Cronin, 2001) and it is possible to identify many of SERVQUAL dimensions in Grönroos (1984) two-component model of service quality. In this study, the author has adopted the technical and functional dimensions of service quality to assess services provided by WISPs.

\section{Technical Quality}

Technical quality refers to the core services or the actual service outcomes (Grönroos, 1983; Lovelock, 1996). According to Hauser and Clausing (1988) technical quality refers to the intended set of technical/engineering attributes, characteristics, and activities which completely define a product/service from a technical/engineering point of view. In order to identify the determinants 
of technical quality for any service, the researchers typically use qualitative methods. Some researchers used openended surveys (Brady \& Cronin, 2001) and others employed depth interviews (Richard \& Allaway, 1993; Powpaka, 1996).

\section{Functional Quality}

According to Grönroos (1983) functional quality refers to "how" the service is delivered and it highlights the nature of the interaction between the serviceproviderand the customer. The process includes courteous attention, professionalism, proper presentation and adequate explanations regarding the service offerings, insightful suggestions and useful recommendations with the customers' best interest at heart, and responding to customer queries and complaints promptly. According to Sharma Patterson (1999) core services (technical quality) become a commodity as competition increases and the industry becomes mature; then functional quality dimension becomes increasingly important to achieve competitive advantage. In order to measure functional quality (process of service delivery) some researchers utilized SERVQUAL items (Brady \& Cronin, 2001; Powpaka, 1996; Richard \& Allaway, 1993).

\section{Communication Effectiveness}

The role of communication in establishing and maintaining profitable stakeholder relationships is quite essential (Holden \& O'Toole, 2004). Duncan (2002) said that marketing communication is a process for managing the customer relationships in such a way that the brand value can be enhanced; which is equally applicable to services as well. According to Anderson and Narus (1990) communication is "the formal as well as informal sharing of meaningful and timely information between firms" (or exchange partners). According to Rouse and Rouse (2002) effective communication means the information is received accurately in terms of content and meaning as intended by the sender. Celuch, Bantham, and Kasouf (2006) highlighted that communication should aid in exchange partners' problemsolving. Communication in relationship marketing refers to keeping in touch with the customers, delivering timely and trustworthy information, and communicating proactively if any problem occurs concerning the interest of the customers (Ndubisi, 2007).

Effective communications are supposed to educate the customers, inform them about the service offerings, and help them to understand the worth/quality of the service being received (Headley \& Choi, 1992). According to Sharma and Patterson (1999) effective communications can corroborate customer understanding of services being received and thus the customers confidently assess the quality and outcomes of the service. Schultz, Tannenbaum, and Lauterborn (1995) said that it is impossible for a marketer to establish effective communication with the target customers by relying on only mass techniques like advertising, sponsorship, and publicity. Effective communication requires the marketer to focus on building rapport, using empathy and dialogue, and such communication distinguishes it from its competitors.

\section{Trust}

Researchers have established that trust is essential for building and maintaining longterm relationships (Rousseau, Sitkin, Burt, \& Camerer, 1998; Singh \& Sirdeshmukh, 2000). Moorman, Deshpande, and Zaltman (1993) defined trust as the willingness of an 
exchange partner to rely on the other party in whom the former has confidence (Hadjikhani $\&$ Thilenius, 2005). In other words, trust refers to a party's reliance and positive expectations on/towards another to achieve a desired outcome (Beatty, Mayer, Coleman, Reynolds, \& Lee, 1996). According to Sirdeshmukh, Singh, and Sabol (2002), trust is customer-held expectations whether the service provider "can be relied on to deliver on its promises". Doney and Cannon (1997) referred to trust as the perceived credibility and benevolence of a party.

From Anderson and Narus (1990) it is gathered that if one party believes that the actions of the other party will bring positive outcomes to the first party, trust starts to develop. Doney and Cannon (1997) also said that the trusted party must have the ability to meet its obligations towards the customer and continue to do so in the future. Liang and Wang (2008) added that trusted party should be willing to make sacrifices to satisfy the customers' needs in the relationship. According to Lau and Lee (1999) if one party trusts another party it will eventually engender positive behavioural intentions towards the second party. When discussing the role of trust in their study, Sharma and Patterson (1999) said that trust plays a vital role in motivating the customers to continue their relationships with the service provider.

\section{Relationship Commitment}

Commitment has been defined as "an implicit or explicit pledge of relational continuity between exchange partners" (Dwyer, Schurr, \& Oh, 1987). Commitment is considered to be an essential antecedent to customer retention (Evanschitzky, Iyer, Plassmann, Niessing, \& Meffert, 2006). Relationship commitment exists when an exchange partner considers that the existing relationship (with the other party) is really important and s/he is willing to exert the required efforts (Morgan \& Hunt, 1994) or invest necessary resources (Gounaris, 2005; Theron, Terblanche, \& Boshoff, 2008; Wilson, 1995) to maintain that relationship. According to Anderson and Weitz (1992) and Kumar et al. (1995) relationship commitment is considered to be a critical element for long-term business success. According to Moorman et al. (1992) relationship commitment refers to an enduring attempt to retain a valued relationship. Garbarino and Johnson (1999) identified commitment with the customers' feeling of adoration, loyalty, concern regarding their blessings, agreement and even pride towards a company. In order to understand commitment-based customer-firm relationships better, three types of commitment (affective, normative, and calculative/continuance) should be considered (Meyer \& Allen, 1997). However, marketing research generally focuses on affective and continuance commitment (Fullerton, 2003). In this study, the author has also focused on affective and continuance commitment.

\section{Relationship between Technical Quality and Relationship Commitment}

Sharma and Patterson (1999) reported that technical quality has a strong and significant direct impact on relationship commitment. If technical quality is continually improved and more attention is paid to service outcome(s), customers not only become satisfied, but also become more committed in the relationship with service provider (Wetzels, Ruyter, \& Birgelen, 1998).

Hypothesis 1: There is a positive and significant relationship between technical quality and relationship commitment. 


\section{Relationship between Functional Quality and Relationship Commitment}

As mentioned by Grönroos (1978) functional quality has a definite impact on customers' relationship commitment or loyalty towards the service provider. Sharma and Patterson (1999) claimed that higher perceived functional quality will result in higher trust in the relationship with the service provider, eventually leading to higher relationship commitment.

Hypothesis 2: There is a positive and - significant relationship between functional quality and relationship commitment.

\section{Relationship between Communication} Effectiveness and Relationship Commitment

For a continuous buyer-seller relationship, effective and timely communication is almostessential. How communication affects the commitment or relational pledge of an exchange partner is addressed by several studies (Adamson et al., 2003; Goodman \& Dion, 2001; Sharma \& Patterson, 1999). According to Prashinski and Fan (2007) communication quality is one of the most critical aspects of the business relationship (Mohr, Fisher, \& Nevin, 1996) as receiver's perception of communication quality has an effect on the receiver's response to the information (Maltz, 2000). Morgan and Hunt (1994) stated that timely communication can engender trust by helping to resolve disputes and align perceptions and expectations and eventually such effective communication can increase trust between parties and boost their relationship.

Hypothesis 3: There is a positive and significant relationship between communication effectiveness and relationship commitment.
Relationship between Trust and Relationship Commitment

Each partner's ability to provide positive outcomes to the other determines the level of commitment to the relationship. Trust therefore, happens to be a major determinant of relationship commitment (Morgan and Hunt, 1994), and exists when there is mutual confidence in the exchange partner's reliability and integrity. The relationship between trust and commitment happens to be a well-documented one, and several studies have confirmed the positive impact of trust on the exchange partner's commitment to a relationship (Beatty et al., 1996; Caceres \& Paparoidamis, 2007; Doney \& Cannon, 1997; Dwyer, Schurr \& Oh, 1987; Garbarino \& Johnson, 1999; Morgan \& Hunt 1994; Mukherjee \& Nath, 2003; Razzaque \& Boon, 2003; Tellefsen \& Thomas, 2005; Wilson, 1995). Many researchers have reported that customers' trust has a significant role in building longterm relationship and fostering customer loyalty (Bowen \& Shoemaker, 2003; Chu, 2009) and trust between parties can enhance relationship quality (Farrelly \& Quester 2003; Mouzas, Henneberg , \& Naude 2007). Like Sharma and Patterson (1999) Anderson and Sharpe (2008) have also discussed the interrelation between trust and commitment in the field of financial planning or advisory services. Higher trust is identified as a critical factor for relational success between the customer and the business (Huang \& Chiu, 2006), since trust reduces uncertainty when a customer feels vulnerable and there is a trustworthy partner (Aydin \& Ozer 2005).

Hypothesis 4: There is a positive and significant relationship trust and relationship commitment. 


\section{Conceptual Framework}

Based on the literature review, the abovementioned hypotheses have been used to develop the conceptual framework (Figure 1). The main objective of the study is to examine the role of these key antecedents of subscribers' relationship commitment. Two dimensions of service quality (i.e. technical quality, functional quality), communication effectiveness, and trust are the independent variables (IV) and relationship commitment is the dependent variable (DV).

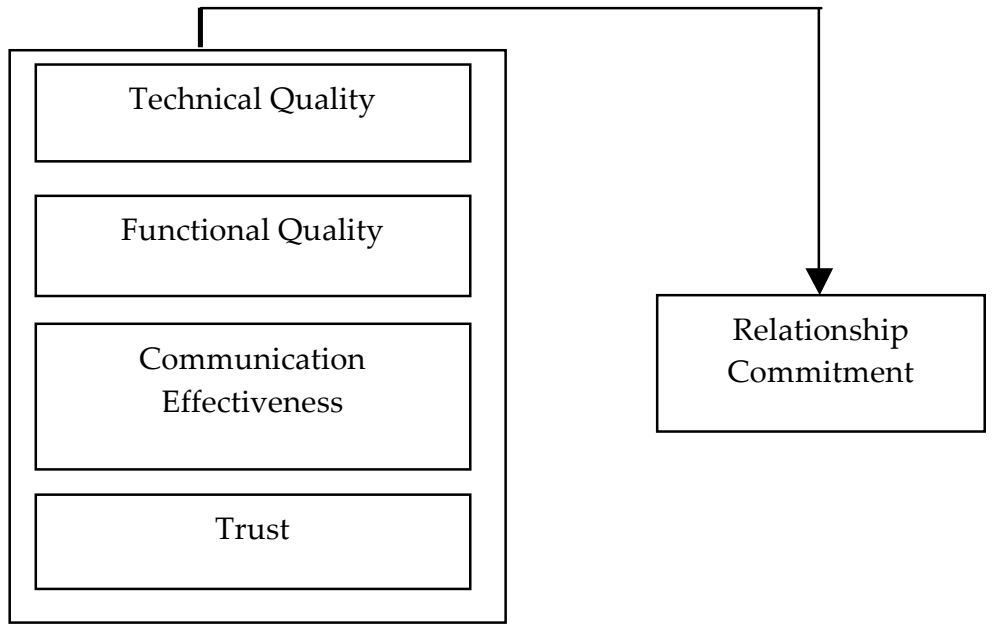

Figure 1. Conceptual framework.

Methodology

\section{Sampling and Data Collection}

The author used the area-wise quota sampling. Data collection was limited to the Dhaka metropolitan area and the city was divided into four areas. A total of 200 (50 questionnaires for each area) structured questionnaires were distributed among the WIS subscribers (who had been receiving the service for a year or so) of the leading WISP in Bangladesh. The survey via personal interview was used for data collection purpose. Hence, 193 completed questionnaires were collected. Due to missing data problems 21 questionnaires were dropped from the data analysis and finally 172 questionnaires were used. The average age of the respondents was 28 years. $67 \%$ of the respondents were male and 33 $\%$ were female. $78 \%$ of the respondents had more than 12 years of education. $29 \%$ of the respondents were students, $44 \%$ were service holders, and $27 \%$ were self-employed.

\section{Measurement Instruments}

The questionnaire was comprised five sections meant for five variables where the 
author used the 5-point Likert scale like previous researchers. The technical quality of service-scale germane to WIS was measured by using 10 items; which were a combination of items adopted from Sharma and Patterson (1999) and the author's prior qualitative research ${ }^{\mathbf{1}}$.

Five (5) items to measure functional quality were collected from Sharma and Patterson (1999) and the author's prior qualitative research. Communication effectiveness was measured by using 6 items which were collected from Anderson and Weitz (1992); Sharma and Patterson (1999) and the author's prior research. Trust was measured by 5 items, which were adopted from Moorman et al. (1992), Crosby et al. (1990), and Sharma and Patterson (1999). Relationship commitment had 4 items and those were adopted from Anderson and Weitz (1992), and Morgan and Hunt (1994). As found in the literature, the reported reliability coefficients (Cronbach alpha) of all the scales ranged from 0.68 to 0.90 .

\section{Data Analysis}

The author has employed both descriptive and inferential statistics. Correlation analysis and stepwise regression were carried out by using SPSS version 12.

Table 1

Descriptive Statistics and Reliability Coefficients $(n=172)$

\begin{tabular}{lcccc} 
Scales & Number of items & $\underline{\text { Alpha }}$ & $\underline{\text { M }}$ & $\underline{\text { SD }}$ \\
\hline Technical quality & 10 & 0.73 & 3.68 & 0.47 \\
Functional quality & 5 & 0.76 & 3.73 & 0.51 \\
Communication effectiveness & 6 & 0.87 & 3.49 & 0.46 \\
Trust & 5 & 0.69 & 3.61 & 0.54 \\
Relationship commitment & 4 & 0.80 & 3.70 & 0.62 \\
\hline
\end{tabular}

\section{Results}

Descriptive Statistics and Reliability Coefficients

Descriptive statistics and reliability coefficients of the studied variables are presented in Table 1. The range of Cronbach alpha of all the scales was 0.69-0.87; which shows that the reliability of all the constructs used in this study are found to be above the standard (i.e. 0.70) set by Nunnally (1978) except trust. According to Kline (1999) for psychological constructs, considering the diversity of the construct studied, a slightly lower value than 0.70 can be expected. Hence, the author decided to proceed further with the scale 'trust'.

Mean scores of all the variables measured on a five-point Likert scale are found to have a range of 3.49 to 3.73 and the corresponding standard deviations ranged from 0.46 to 0.62 . These mean scores indicate that the subscribers' appraisal of technical quality, functional quality, communication effectiveness, trust, and relationship commitment are above average. 


\section{Correlation Analysis}

A correlation analysis was done on all the variables in this study for two purposes. Firstly, it was for checking the presence of multicollinearity, which would be revealed when the inter-construct correlations for explanatory variables exceeded 0.80 (Berry \& Feldmann, 1985). However, later on, variance inflation factor (VIF) and tolerance values for all the variables were checked. VIF values (ranging from 1.754-1.538) were less than 10.0, and tolerance values (ranging from $0.570-0.844$ ) were greater than 0.10 but less than 1.0 and these values suggest the absence of multicollinearity (Kline, 2005). Secondly, correlation analysis was for helping to explore the relationships between the independent and the dependent variables. The bivariate correlation procedure was subjected to two-tailed tests of statistical significance at two different levels- highly significant $(\mathrm{p}<.01)$ and significant $(\mathrm{p}<.05)$. Correlation matrix is presented in Table 2. All the correlations support the notion of the hypothesized positive relationships among the independent variable(s) and the dependent variable with high statistical significance $(\mathrm{p}<.01)$.

Table 2

Correlation Matrix $(n=172)$

\begin{tabular}{lccccc}
\hline \multicolumn{1}{r}{ Variables } & TEC_QLTY & FNC_QLTY & COM_EFF & TRUST & REL_COM \\
\hline TEC_QLTY & - & $0.23^{* *}$ & $0.39^{* *}$ & $0.59^{* *}$ & $0.54^{* *}$ \\
FNC_QLTY & - & $0.38^{* *}$ & $0.20^{* *}$ & $0.31^{* *}$ \\
COM_EFF & & - & $0.18^{*}$ & $0.41^{* *}$ \\
TRUST & & & - & $0.52^{* *}$ \\
REL_COM & & & & - \\
\hline
\end{tabular}

Note: $* \mathrm{p}<.05, * * \mathrm{p}<.01$.

\section{Stepwise Regression Analysis}

The method used to predict the subscribers' relationship commitment was multiple regression analysis. The variables were entered into the model using the stepwise method. The prediction model contained four predictors (technical quality, functional quality, trust, and communication effectiveness) and was reached in three steps with one variable (functional quality) removed. The relevant results are presented in Table 3.
The model was statistically significant, $F$ $(3,169)=38.81, p<.001$, and accounted for approximately $40.9 \%$ of the variance of relationship commitment $(R 2=.409$, Adjusted $R 2=.399)$. The results show that the Model 1, Model 2, and Model 3 are statistically significant (Model 1: $\mathrm{F}=69.014$, $\mathrm{p}=0.000 ;$ Model 2: $\mathrm{F}=46.116, \mathrm{p}=0.000$; Model 3: $\mathrm{F}=38.810, \mathrm{p}=0.000$ ). 
Relationship commitment was primarily predicted by technical quality. The results show that the three variables used in the model are statistically significant in predicting relationship commitment and $40.9 \%$ of the variability in relationship commitment can be accounted for by these predictors (technical quality, trust, and communication effectiveness). The $\mathrm{R}^{2}$ for regression of Model 1 comprised technical quality (IV) and relationship commitment (DV) was 0.289. The $\mathrm{R}^{2}$ for regression of Model 2 comprised technical quality (IV), trust (IV), and relationship commitment (DV) was 0.353 . Trust only made 0.064 or $6.4 \%$ improvement in the model in terms of explaining the variation or change in relationship commitment. The $\mathrm{R}^{2}$ for regression of Model 3 comprised technical quality (IV), trust (IV), communication effectiveness (IV), and relationship commitment (DV) was 0.409 . Communication effectiveness only made 0.056 or $5.6 \%$ improvement in the model.

Functional quality was found not to have a statistically significant relationship with relationship commitment. These results provide support to hypothesis 1 , hypothesis 3 , and hypothesis 4 . The regression model derived from Table 3 is:

Relationship commitment $=0.261+$ 0.355 (Technical quality) +0.433 (Trust) + 0.308 (Communication effectiveness).

Table 3

Stepwise Regression on Relationship Commitment

\begin{tabular}{|c|c|c|c|c|c|c|c|c|c|c|c|}
\hline Model & Variables & $\mathrm{b}$ & $S E-b$ & Beta & $\mathrm{t}$ & Sig. & $\mathrm{F}$ & Sig. & $\mathrm{R}^{2}$ & $\begin{array}{l}\text { Adjusted } \\
\text { R2 }\end{array}$ & $\Delta \mathrm{R}^{2}$ \\
\hline \multirow[t]{2}{*}{1} & (Constant) & .301 & .059 & - & 5.102 & .000 & 69.01 & .000 & .289 & .285 & - \\
\hline & Technical quality & .793 & .096 & .537 & 8.307 & .000 & & & & & \\
\hline \multirow[t]{3}{*}{2} & (Constant) & .295 & .061 & - & 4.841 & .000 & 46.12 & .000 & .353 & .345 & $6.4 \%$ \\
\hline & Technical quality & .520 & .113 & .352 & 4.603 & .000 & & & & & \\
\hline & Trust & .409 & .100 & .314 & 4.099 & .000 & & & & & \\
\hline \multirow[t]{4}{*}{3} & (Constant) & .261 & .064 & - & 4.074 & .000 & 38.81 & .000 & .409 & .399 & $5.6 \%$ \\
\hline & Technical quality & .355 & .116 & .241 & 3.064 & .000 & & & & & \\
\hline & Trust & .433 & .096 & .332 & 4.519 & .000 & & & & & \\
\hline & $\begin{array}{l}\text { Communication } \\
\text { effectiveness }\end{array}$ & .308 & .077 & .258 & 4.001 & .000 & & & & & \\
\hline
\end{tabular}

Note: Dependent Variable: Relationship commitment. ${ }^{*} \mathrm{p}<.05, * * \mathrm{p}<.01$.

\section{Discussion}

The present study is noteworthy for a special reason. Based on the knowledge of the author, no such study has been carried out previously on the subscribers of WISPs in Bangladesh to analyse the effects of technical quality, functional quality, communication 
effectiveness, and trust on relational commitment. Sharma and Patterson (1999) used the same variables in a study for personal financial planning services.

In general, the results have supported most of the hypothesized relationships. The results suggest that nothing is more important than technical quality when it comes to developing subscribers' relationship commitment. It appears that poor technical quality can be quite damaging for relationship commitment. Caceres and Paparoidamis (2007) also reported that service-quality dimensions (technical as well as functional) had a significant effect on relationship satisfaction. To be exact, technical quality is reported to have a stronger effect on relationship satisfaction than functional quality. In turn, relationship satisfaction very strongly influenced commitment and loyalty. In this study, technical quality alone has exhibited the strongest effect on relationship commitment. Hence, WISPs should take initiatives to improve the technical aspects of their services and ensure better technical support to strengthen subscribers' relationship commitment. Strong positive impact of trust and effective communication is also consistent with the findings of earlier researches. A significant positive effect of trust on commitment has been confirmed by Mukherjee and Nath (2003) in the case of online banking. Wang (2008) claimed that the customers' commitment to a company becomes stronger as they feel the company is trustworthy in its relationship efforts. In order to get the subscribers really committed to the relationship with the service provider, it should focus on delivering accurate, trustworthy, timely, and useful information to assist the subscribers in solving their problems. The role of communication to engender commitment is endorsed in a study by Mohr, Fisher, \& Nevin (1996).
Though functional quality does seem to be a significant variable in this study, it should be given proper consideration (in the light of other relevant empirical evidences) while attempting to understand its role in fostering customer-relationship commitment.

The findings of this study have to be interpreted after considering a few limitations. First, data were collected only from the subscribers of one WISP; so the results cannot be generalized for all the operators. Moreover, as data collection was limited to the Dhaka metropolitan area the findings cannot be generalized for all the subscribers that the operator has throughout the country. Second, the use of confirmatory factor analysis (CFA) should have been done as opposed to merely relying on Cronbach's alpha values, which only check internal consistency of a scale. Finally, the inclusion of other variables like- price perception, corporate image, switching costs, etc., might have made the conceptual framework more robust. In future research endeavors additional variables could be incorporated.

\section{End Notes}

${ }^{1}$ In a prior qualitative research one focus group discussion (with seven regular internet service users) and depth interviews with two technical executives (working with a major WISP) and one ICT consultant were conducted. The main objective of that part of the study was to identify key determinants of technical quality and functional quality for WIS. Initially items pertinent to each scale (collected from available literature) were presented to the engineers and the consultant for review and suggestions regarding adding or deleting item(s). In the next stage, a revised set of items for each construct was presented to the focus group. Later, after incorporating 
the insights and suggestions from the focus group discussion, a further revised set of items was presented to the engineers and the consultant for re-evaluation. That's how the scale for each construct was refined and adopted.

\section{References}

Adamson, I., Chan, K., \& Handford, D. (2003). Relationship marketing: Customer commitment and trust as a strategy for the smaller Hong Kong corporate banking sector. International Journal of Bank Marketing, 21(6/7), 347-358.

Anderson, E., \& Narus, J.A. (1990). A model of distributor firm and manufacturer firm working partnerships. Journal of Marketing, 54, 42-58.

Anderson, C., \& Sharp, D. L. (2008). The efficacy of life planning communication tasks in developing successful planner - client relationships. Journal of Financial Planning, June, 66-76.

Anderson, E., \& Weitz, B. (1992). The use of pledges to build and sustain commitment in distribution channels. Journal of Marketing Research, 29 (February), 18-34.

Aydin, S., \& Ozer, G. (2005). How switching costs affect subscriber loyalty in the Turkish mobile phone market: An exploratory study. Journal of Targeting, Measurement and Analysis for Marketing, 14(2), 141155.

Barber, B. (1983). The logic and limits of trust. New Brunswick, NJ: Rutgers University Press.

Beatty, S. E., Mayer, M., Coleman, J. E., Reynolds, K. E., \& Lee, J. (1996). Customer-sales associate retail relationships, Journal of Retailing, 72(3), 223-47.

Berry, W., \& Feldmann, S. (1985). Multiple regression in practice. CA: Sage Publications.

Bolton, R. N., \& Drew, H. J. (1991). A multistage model of customers' assessments of service quality and value. Journal of Consumer Research, (4), 375-84.

Bowen, J. T., \& Shoemaker, S. (2003). Loyalty: A strategic commitment. Cornell Hotel and Restaurant Administration Quarterly, Oct-Dec 2003, 44, 5/6, 31-46.

Brady, M. K., \& Cronin, J. J. (2001). Some new thoughts on conceptualizing perceived service quality: A hierarchical approach. Journal of Marketing, 65(3), 34-49.

Caceres, R. C., \& Paparoidamis, N. G. (2007). Service quality, relationship satisfaction, trust, commitment and business-to-business loyalty. European Journal of Marketing, 41 (7/8), 836-867.

Carman, J. M. (1990). Consumer perceptions of service quality: An assessment of SERVQUAL Dimensions. Journal of Retailing, 66(2), 33-55.

Celuch, K. G., Bantham, J. H., \& Kasouf, C. J. (2006). An extension of the marriage metaphor in buyer-seller relationships: An exploration of individual level process dynamics. Journal of Business Research, 59, 573-581.

Chu, K. M. (2009). The construction model of customer trust, perceived value and customer loyalty. The Journal of American Academy of Business, Cambridge, 14(2), 98-103.

Cronin, J. J. Jr., \& Taylor, S. A. (1992). Measuring service quality: A reexamination and extension. Journal of Marketing, 56(3), 55-68. 
Crosby, L. A., Evans, K. R., \& Cowles, D. (1990). Relationship quality in services selling: An interpersonal influence perspective. Journal of Marketing, 54, 68-81.

Doney, P., \& J. Cannon (1997). An examination of the nature of trust in buyer-seller relationships. Journal of Marketing, 61, 35-51.

Dotchin, J. A., \& Oakland, J. S. 1994. Total quality management in services part 2: Service quality. International Journal of Quality \& Reliability Management, 11(3), 27-42.

Duncan, T. (2002). IMC: Using advertising and promotion to build brands. Burr Ridge: McGraw-Hill/ Irwin.

Dwyer, F. R., Schurr, P. H., \& Oh, S. (1987). Developing buyer-seller relationships. Journal of Marketing, 51,11-27.

Evanschitzky, H., Iyer, G.R., Plassman, H., Niessing, J., \& Meffert, H. (2006). The relative strength of affective commitment in securing loyalty in service relationships. Journal of Business Research, 59, 1207-1213.

Farrelly, F., \& Quester, P. (2003). The effects of market orientation on trust commitment. European Journal of Marketing, 37(3), 530-555.

Fullerton,G.(2003). When does commitment lead to loyalty? Journal of Service Research, 5(4), 333-354.

Garbarino, E., \& Johnson, M. S. (1999). The different roles of satisfaction, trust, and commitment in customer relationships. Journal of Marketing, 63(4), 70-87.

Goodman, L. E., Dion, P. A. (2001). The determinants of commitment in the distributor manufacturer relationship. Industrial Marketing Management, 30(3), 287-300.
Gounaris, S.P.(2005). Trust and commitment influences on customer retention: Insights from business to-business services. Journal of Business Research, 58(2), 126-140.

Grönroos, C. (1978). A service oriented approach to marketing of service. European Journal of Marketing, 12(8), 588-601.

Grönroos, C. (1983). Strategic management and marketing in the service sector. Marketing Science Institute, Boston, MA.

Grönroos, C. (1984). A service quality model and its marketing implications. European Journal of Marketing, 18(4), 36-44.

Hadjikhani, A., \& Thilenius, P. (2005). The impact of horizontal and vertical connections on relationships: Commitment and trust. The Journal of Business \& Industrial Marketing, 20(2/3), 136-148.

Hauser, J., \& Clausing, D. (1988). The house of quality. Harvard Business Review, 66(3), 63-73.

Headley, D.E., \& Choi, B. (1992).Achieving service quality through gap analysis and a basic statistical approach. Journal of Services Marketing, 6 (1), 5-14.

Holden, M. T., \& O'Toole, T. (2004). Affirming communication's primary role in a manufacturer-retailer context. Journal of Marketing Management, 20(9/10), 1047.

Hougaard, S., \& Bjerre, M. (2002). Strategic relationship marketing, Samfundslitteratur Press.

Huang, H. H., \& Chiu, C. K. (2006). Exploring customer satisfaction, trust and destination loyalty in tourism. Journal of American Academy of Business, 10(1), 156159. 
Hunt, S. D., Arnett, D. B., \& Madhavaran, S. (2006).The explanatory foundations of relationship marketing theory. Journal of Business \&Industrial Marketing, 21(2) 72-87.

Imrie, B. C., Cadogan, J.W., \& McNaughton, R. (2002). The service quality construct on a global stage. Managing Service Quality, 12(1), 10-18.

Kline, P. (1999). The handbook of psychological testing (2nd ed.). London: Routledge.

Kline, R. B. (2005). Principles and practice of structural equation modeling (2nd ed.). New York: The Guilford Press.

Kumar, N., Scheer, L. K., \& Steenkamp, J-B. E.M.(1995).The effects of perceived interdependence on dealer attitudes. Journal of Marketing Research, 32(8), 348-356.

Lau, G., \& Lee, S. (1999). Consumers' trust in a brand and link to brand loyalty. Journal of Market Focused Management, 4, 341-70.

Liang, C. J., \& Wang, W. H. (2008). Do loyal and more involved customers reciprocate retailer's relationship efforts? Journal of Services Research, 8(1), 63-90.

Lovelock, C. H. (1996). Services marketing (3rd ed.). London: Prentice-Hall.

Maltz, E. (2000). Is all communication created equal? An investigation into the effects of communication mode on perceived information quality. Journal of Product Innovation Management, 17(2), 110-127.

Meyer, J. P., \& Allen, N. J. (1997). Commitment in the workplace: Theory, research and application. Thousand Oaks, CA: Sage.

Mohr,J.J.,Fisher, R.J., \& J.R. Nevin.(1996). Collaborative communication in inter firm relationships: Moderating effects of integration and control. Journal of Marketing, 60(7), 103115.

Moorman, C., Deshpande, R., \& Zaltman, G. (1993). Factors affecting trust in market research relationships. Journal of Marketing, 57(1), 81101.

Morgan, R. M., \& Hunt, S. D. (1994). The commitment-trust theory of relationship marketing. Journal of Marketing, 58(7), 20-38.

Mouzas, S., Henneberg, S., \& Naude, P. (2007). Trust and reliance in business relationships. European Journal of Marketing, 41(9), 1016-1032.

Mukherjee,A., \& Nath, P. (2003). A model of trust in online relationship Banking. The International Journal of Bank Marketing, 21(1), 5-15.

Ndubisi, N. O. (2007). Relationship marketing \& customer loyalty. Marketing Intelligence \& Planning, 25(1), 98-106.

Nunnally, J. C. (1978). Psychometric theory (2nd ed.). New York: McGraw Hill.

Oliver, R. L. (1989). Processing of the satisfaction response in consumption: A suggested framework and research propositions. Journal of Consumer Satisfaction, Dissatisfaction and Complaining Behavior, 2, 1-16.

Palmer, A., \& Bejou, D. (1994). Buyer-seller relationships: A conceptual model and empirical investigation. Journal of Marketing Management, 10(6), 495-512.

Parasuraman, A., Zeithaml, V. A., \& Berry, L. L. (1985). A conceptual model of service quality and its implications for future research. Journal of Marketing, 49(Fall), 41-50. 
Parasuraman, A., Zeithaml, V. A., \& Berry, L. L. (1988). SERVQUAL: A multiple-item scale for measuring consumer perceptions of service quality. Journal of Retailing, 64 (Spring), 12-40.

Powpaka, S. (1996). The role of outcome quality as a determinant of overall service quality in different categories of services industries: An empirical investigation. Journal of Services Marketing, 10(2), 5-25.

Prahinski, C., \& Fan, Y. (2007). Supplier evaluations: The role of communication quality. The Journal of Supply Chain Management, Summer, 16-28.

Rahman, M. (2011). WiMax operators set to go aggressive. The Independent. Retrieved from http://www. theindependentbd.com/

Razzaque, M. A., \& Boon, T. G. (2003). Effects of dependence and trust on channel satisfaction, commitment and cooperation. Journal of Business-to-Business Marketing, 10(4), 23-48.

Rouse, M. J., \& Rouse, S. (2002). Business communications: A cultural and strategic approach. Australia: Thomson Learning.

Rousseau, M. T., Stikin, S. B., Burt, S. B., \& Carmerer,C. (1998). Not so different after all: Across-discipline view of trust. Academy of Management Review, 23(3), 393-404.

Schultz, D. E., Tannenbaum, S. I., \& Lauterborn, R. F. (1995). The new marketing paradigm: IMC. Chicago: NTC Business Books.

Sharma, N., \& Patterson, G. P. (1999). The impact of communication effectiveness and service quality on relationship commitment in consumer, professional services. The Journal of Services Marketing, 13(2), 151-170.

Singh, J., \& Sirdeshmukh, D. (2000). Agency and trust mechanisms in customer satisfaction and loyalty judgements. Journal of the Academy of Marketing Science, 28(1), 150-67.

Singh, R. (2011). Bangladesh-long way to go. Voice Data. Retrieved from http://voicendata.ciol.com/

Sirdeshmukh, D., Singh, J., \& Sabol, B. (2002). Consumer trust, value and loyalty in relationship exchanges, Journal of Marketing, 66(1), 15-37.

Taylor, S. A. (1995). The effects of filled waiting time and service provider control over the delay on evaluations of service. Journal of the Academy of Marketing Science, 23(1), 38-48.

Tellefsen, T., \& Thomas, G. P. (2005). The antecedents and consequences of organizational and personal commitment in business service relationships. Industrial Marketing Management, 34(1), 23-37.

Theron, E., Terblanche, N. S., \& Boshoff, C. (2008). The antecedents of relationship commitment in the management of relationships in business-to-business (B2B) financial services. Journal of Marketing Management, 24(9-10), 997-1010.

Wang, W. H. (2008). The interrelationship of retailer's relationship efforts and consumers' attitude and behavior. Measuring Business Excellence, 12(1), 13-28.

Wetzels, M., Ruyter, de Ko, \& Brigelen, M. V. (1998). Marketing service relationships: The role of commitment. Journal of Business \& Industrial Marketing, 13(4-5), 40623. 
Wilson, D. T. (1995). An integrated model of buyer-seller relationships.Journal of the Academy of Marketing Science, 23(4), 335-345.

Zeithaml, V. A. (2000). Service quality, profitability, and the economic worth of customers: What we know and what we need to learn. Journal of the Academy of Marketing Science, 28(1), 67-85.
Zeithaml, V. A., Parasuraman, A., \& Berry, L. L. (1990). Delivering quality service: Balancing customer perceptions and expectations. New York: The Free Press.

Zins, A. H. (2001). Relative attitudes and commitment in customer loyalty models: Some experiences in the commercial airline industry. International Journal of Service and Industry Management, 12(3), 269-94. 